\title{
In Vivo Imaging of CNS Injury and Disease
}

\author{
๑ Katerina Akassoglou, ${ }^{1,2 \star}$ Mario Merlini, ${ }^{1}$ Victoria A. Rafalski, ${ }^{1}$ Raquel Real, ${ }^{3}$ @Liang Liang, ${ }^{4,5 *}$ Yunju Jin, ${ }^{6,7}$ \\ Sarah E. Dougherty, ${ }^{6}{ }^{\circ}$ Vincenzo De Paola, ${ }^{3 *}{ }^{*}$ David J. Linden, ${ }^{6 *}$ Thomas Misgeld, ${ }^{8 *}$ and Binhai Zheng ${ }^{9 *}$ \\ ${ }^{1}$ Gladstone Institutes; San Francisco, California 94158, ${ }^{2}$ Department of Neurology, University of California San Francisco, San Francisco, California 94158, \\ ${ }^{3}$ Institute of Clinical Sciences, Faculty of Medicine, Imperial College London, London W12 0NN, United Kingdom, ${ }^{4}$ F.M. Kirby Neurobiology Center, Boston \\ Children's Hospital, Harvard Medical School, Boston, Massachusetts 02115, ${ }^{5}$ Division of Endocrinology, Diabetes and Metabolism, Department of \\ Medicine, Beth Israel Deaconess Medical Center, Harvard Medical School, Boston, Massachusetts 02215, ${ }^{6}$ Solomon H. Snyder Department of Neuroscience, \\ School of Medicine, Johns Hopkins University, Baltimore, Maryland 21205, ${ }^{7}$ Center for Cognition and Sociality, Institute for Basic Science, Daejeon 34141, \\ Republic of Korea, ${ }^{8}$ Technical University of Munich, Institute of Neuronal Cell Biology, Munich Center for Systems Neurology, German Center for \\ Neurodegenerative Diseases, 80802 Munich, Germany, and ${ }^{9}$ Department of Neurosciences, School of Medicine, University of California San Diego, La Jolla, \\ California 92093
}

In vivo optical imaging has emerged as a powerful tool with which to study cellular responses to injury and disease in the mammalian CNS. Important new insights have emerged regarding axonal degeneration and regeneration, glial responses and neuroinflammation, changes in the neurovascular unit, and, more recently, neural transplantations. Accompanying a 2017 SfN Mini-Symposium, here, we discuss selected recent advances in understanding the neuronal, glial, and other cellular responses to CNS injury and disease with in vivo imaging of the rodent brain or spinal cord. We anticipate that in vivo optical imaging will continue to be at the forefront of breakthrough discoveries of fundamental mechanisms and therapies for CNS injury and disease.

Key words: blood-brain barrier; iPSCs; microglia; retina; two-photon imaging

\section{Introduction}

Understanding the multicellular response to injury and disease in the mammalian CNS provides a foundation for the development of therapeutic strategies for a variety of neurological conditions. Studies with animal models rely heavily on histological analyses of terminal samples as obligatory outcome measures. In vivo optical imaging provides an alternative and complementary approach to investigating the molecular, cellular, and physiological events after CNS injury and disease (Misgeld and Kerschensteiner, 2006). Advanced optical imaging technologies such as multiphoton microscopy (Denk et al., 1990) offer certain advantages over wide-field fluorescence microscopy, including deeper tissue penetration and less phototoxicity, which are conducive to repeated in vivo imaging.

\footnotetext{
Received Aug. 22, 2017; revised 0ct. 2, 2017; accepted 0ct. 3, 2017.

This work was supported by the National Institutes of Health (Grant NS097976 to K.A.; Grant NS096920 to V.A.R.; Grants NS081467, MH100024, NS095907, and NS095879 to D.J.L.; Grants NS093055, NS054734 to B.Z., and NS047101 to the UCSD Neuroscience Microscopy P30 (enter), the National MS Society (Grant RG4985A3), the Department of Defense (Grant MS160082), the Conrad N. Hilton Foundation (K.A.), the Medical Research Council UK (V.D.P.), Alzheimer's Research UK (V.D.P.), Portuguese funding agency for science, research and technology and Rosetrees Trust (R.R. and V.D.P.), the Simons Foundation (L.L.), the Harvard/Massachusetts Institute of Technology Joint Research Grants Program in Basic Neuroscience (C.C. and M.L.A.), the German Research Foundation (EXC1010, EXC114, SFB870, Mi694/7-1 and 8-1 to T.M.), the European Research Council (FP/2007-2013, 616791 to T.M.), and the Dana Foundation (B.Z.). L.L. thanks Chinfei Chen and Mark L. Andermann for mentorship and support.

The authors declare no competing financial interests.

*K.A., L.L., V.D.P., D.J.L., T.M., and B.Z. contributed equally to this work.

Correspondence should be addressed to either of the following: Dr. Katerina Akassoglou, Gladstone Institute of Neurological Disease and Department of Neurology, University of California San Francisco, 1650 Owen St., San Francisco, CA, E-mail: katerina.akassoglou@gladstone.ucsf.edu; or Dr. Binhai Zheng, Department of Neurosciences, School of Medicine, University of California San Diego, 9500 Gilman Dr., La Jolla, CA, E-mail: bizheng@ucsd.edu.

DOI:10.1523/JNEUROSCI.1826-17.2017

Copyright $\odot 2017$ the authors $\quad 0270-6474 / 17 / 3710808-09 \$ 15.00 / 0$
}

In the past several years, there has been a critical mass in discoveries made with in vivo optical imaging in the injured or diseased CNS. Insights on neuronal, glial, and other cellular responses have been reported that were not previously possible or practical to obtain with endpoint analyses using conventional histological methods. Time-lapse imaging of the same cellular and subcellular structures depicts the dynamic responses to injury and disease at a high spatiotemporal resolution. Imaging at both the acute and chronic time points reveals unanticipated new principles and mechanisms. The time is ripe to have a productive and stimulating discussion on this topic so that the neuroscience community may better capitalize on the power of in vivo imaging to study the injured or diseased CNS.

At the 2017 Society for Neuroscience meeting, we will present selected recent advances in using in vivo optical imaging to understand the multicellular responses to CNS injury and disease (Mini-Symposium: In vivo Imaging of CNS Injury and Disease). Here, we highlight some of these advances, giving consideration to both the Mini-Symposium (topics illustrated in Fig. 1) and the published literature.

In vivo imaging provides unique insights into the axonal responses to minimal injury in the CNS

CNS injuries associated with axon damage are without a cure and often result in severe and permanent disability largely due to the regeneration failure of injured axons (Chen and Zheng, 2014; Geoffroy and Zheng, 2014). In vivo imaging of axonal dynamics in the lesioned CNS is therefore an especially interesting area of investigation because it can potentially inform strategies to promote functional circuit repair after spinal cord and brain injury. 

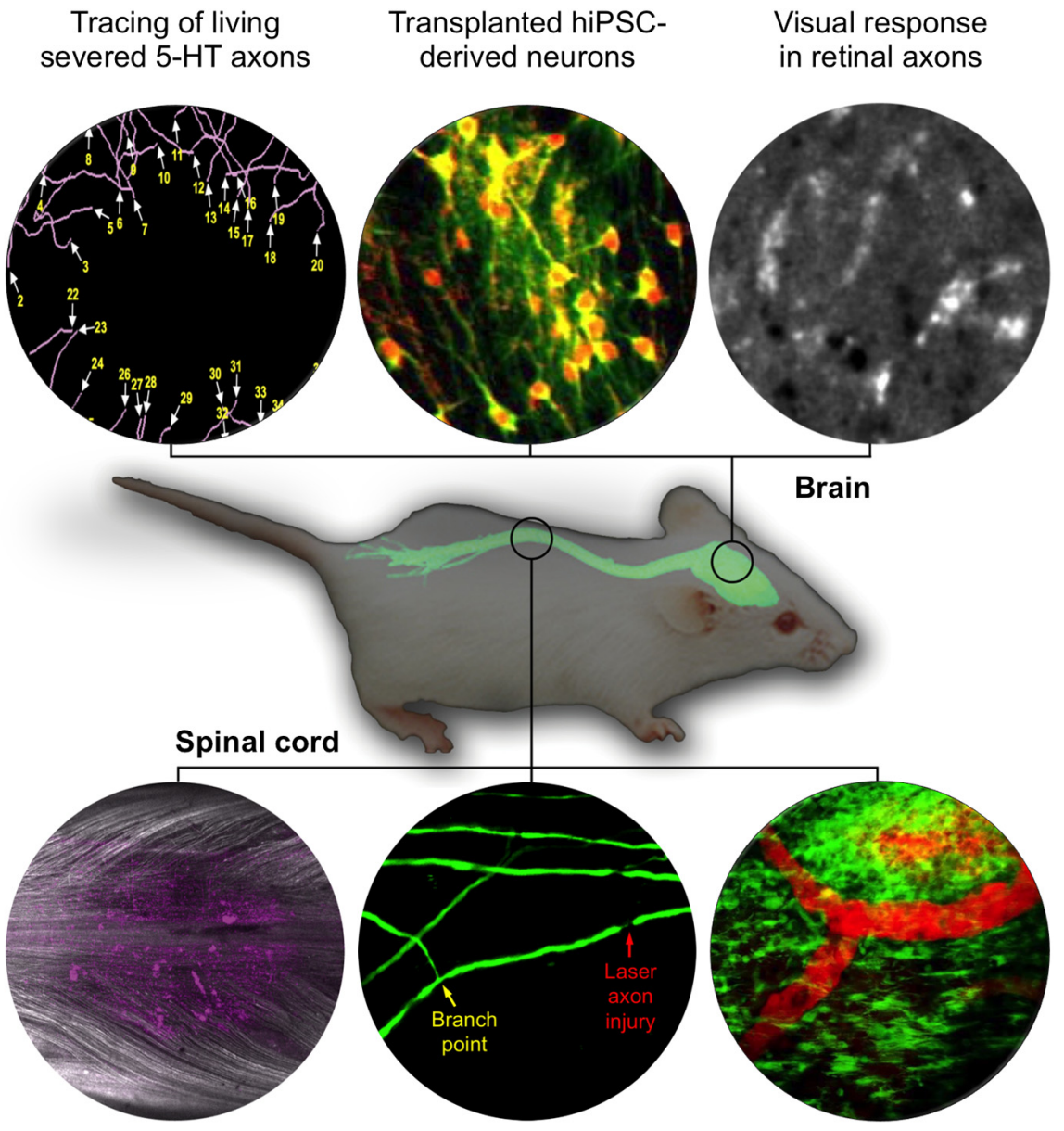

Reversible axon damage after contusion injury

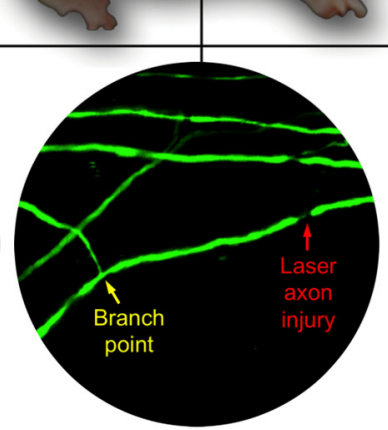

Injury response of axonal branches

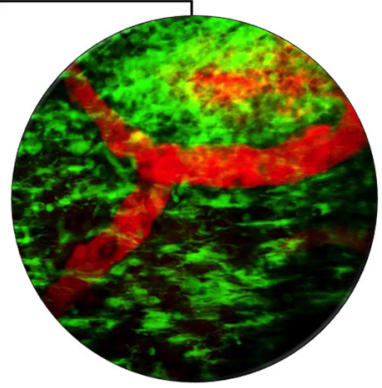

BBB disruption \& neuroimmune responses

Figure 1. In vivo imaging of CNS injury and disease. In vivo imaging of the brain and spinal cord has revolutionized our understanding of CNS pathology including axonal, vascular, and immune responses to CNS injury and disease. Topics illustrated here will be presented at a 2017 SfN Mini-Symposium. Top row, Tracing of living severed mouse serotonin axons in the neocortex (Jin et al., 2016), structural and functional in vivo imaging of transplanted human iPSC (hiPSC)-derived neurons expressing TdTomato (red) and GCaMP6 (green) (Real and De Paola, unpublished data), calcium imaging of visual response in retinal axons (Liang et al., unpublished data) are representative examples of imaging the dynamic responses of neuronal cells in the brain. Bottom row, Imaging the spinal cord after contusion injury (axons in white, cell death marker dye in magenta; Williams et al., 2014), injury response of axonal branches after laser axotomy (Lorenzana et al., 2015), and BBB disruption and microglia responses in autoimmune neuroinflammation (Davalos et al., 2012) illustrates how in vivo imaging allows the study of neuroimmune interactions and axonal responses to injury and disease. At center is an image of a mouse superimposed with the fluorescence image of a dissected central nervous system taken from a Thy1-XFP-transgenic mouse (modified from Misgeld and Kerschensteiner, 2006).

Kerschensteiner et al. (2005) were the first group to demonstrate the utility of in vivo imaging of axonal response to injury in the mammalian CNS. Using wide-field fluorescence microscopy, this study examined the degeneration and regeneration of Thy1-XFPlabeled dorsal column sensory axons (Feng et al., 2000) after a small pinprick injury in the mouse spinal cord. This led to the identification of an acute phase of bidirectional axon degeneration, which differs from the well characterized Wallerian degeneration that occurs distal to the injury site at a later phase (Kerschensteiner et al., 2005).

Since then, spinal cord in vivo imaging has been used to characterize the effect of microtubule stabilization on retraction bulb formation after injury (Ertürk et al., 2007), to demonstrate the sustained responsiveness of a chronically injured dorsal column sensory axon to a conditioning peripheral lesion (Ylera et al.,
2009), to investigate axon-blood vessel interaction in regeneration and neuroinflammatory disease (Dray et al., 2009; Davalos et al., 2012), to illustrate rapid immobilization of regenerating sensory axons after entering the dorsal root entry zone following a dorsal root crush (Di Maio et al., 2011), to reveal a phasespecific role for STAT3 in initiating but not sustaining sensory axon regeneration (Bareyre et al., 2011), and to identify a role of axon-macrophage interaction in subacute axon degeneration after injury (Evans et al., 2014).

Building on an in vivo two-photon imaging method in the mouse spinal cord developed by Davalos et al. (2008), Lorenzana et al. (2015) examined the effect of laseraxotomizing a dorsal column sensory axon just before or after a major branch point. They found that axotomy just proximal to the branch point leads to axonal responses similar to axotomy of an unbranched axon, as illustrated in current neuroscience textbooks. However, when axotomy occurs just distal to the branch point, one branch was practically eliminated by both retrograde and anterograde degeneration, whereas the other branch, still connected to the cell body via the branch point, was typically protected from destruction (Lorenzana et al., 2015). This study illustrates that the axonal branch may serve as a barrier for retrograde degeneration and that a remaining axonal branch stabilizes remaining axon architecture after axotomy to the other branch (presented by B. Zheng, 2017 SfN MiniSymposium). It makes economical sense for neurons to protect whatever synaptic function there is left and to only to attempt to regenerate when all or most synaptic outputs have been lost. The exact mechanisms through which neurons accomplish this remain to be investigated. Meanwhile, this study illustrated dynamic degeneration, regeneration, pruning, and remodeling of dorsal column sensory axons up to 6 months after the initial axotomy.

Relatively less is known about the responses of axons in the injured mammalian brain, where axons can reach total lengths of several tens of centimeters and have extremely elaborate branching patterns to connect to all of their targets. De Paola and colleagues used in vivo two-photon imaging and laser axotomy to illustrate a high level of heterogeneity in the injury response of cortical axons (Canty et al., 2013b). That study focused on the behavior of individual axons in the adult cortical gray matter, a fiber system vulnerable in many degenerative brain disorders. Although some axon types exhibited a low level of regeneration after laser axotomy, others (especially from layer 6 neurons) exhibited a high level of axon regeneration associated with the reestablishment of normal synaptic density. When they did regenerate, these axons exhibited dynamic changes up to 6 months 
after the initial injury (Canty et al., 2013b), similar to the spinal dorsal column sensory axons described above (Lorenzana et al., 2015). Therefore, in both the spinal cord and the brain, in vivo imaging is revealing fundamental properties of axonal responses to a minimal injury. In addition, the development of capabilities to correlate in vivo imaging and electron microscopy allows for ultrastructural examination of optically imaged cellular structures such as axonal boutons (Allegra Mascaro et al., 2013; Canty et al., 2013b) and end bulbs after CNS axon injury (Bishop et al., 2011).

\section{In vivo imaging reveals reversible axon damage in clinically relevant models}

Kerschensteiner and Misgeld and their teams have conducted extensive in vivo imaging studies in animal models of CNS injury and disease. Here, we discuss two studies that collectively illustrate a potentially very important avenue for therapeutic development: to rescue axons that are compromised but not yet fully degenerated (presented by T. Misgeld, 2017 SfN Mini-Symposium). In the first study, Williams et al. (2014) used two-photon in vivo imaging to follow many superficially located spinal axons after a spinal cord contusion injury. They found that some axons became swollen in their morphology. Some of these swollen axons went on to become broken and degenerated; others recovered, meaning that they returned to a more healthy-looking morphology. These recovered axons appeared to sustain and maintain integrity long term (i.e., at least days) after injury. This recoverable state of swollen axons lasts for hours and the fate of the axon depends on intra-axonal calcium such that sustained intra-axonal calcium elevations were associated with axonal degeneration, whereas return of the calcium level to baseline was associated with axonal recovery. Removal of extracellular calcium with a $\mathrm{Ca}^{2+}$ chelator or pharmacologically inhibiting calpain, a calcium-dependent protease, blocks axon degeneration. This study illustrates that axonal rescue, for example, by manipulating intra-axonal calcium, could be a promising strategy to preserve what is left in connectivity and function following a clinically relevant model of spinal cord injury.

In the other study, Nikić et al. (2011) discovered a reversible form of axonal damage in an experimental autoimmune encephalomyelitis (EAE) model of multiple sclerosis, which is analogous to that in the spinal cord contusion injury model discussed above (Williams et al., 2014). In a well characterized myelin oligodendrocyte glycoprotein-induced spinal EAE model, Nikić et al. (2011) identified a state of axonal damage with focal swellings that they termed focal axonal degeneration (FAD). Like the swollen axons after spinal cord contusion injury (Williams et al., 2014), these swollen axons could become fully fragmented and degenerated, but could also recover to healthy-looking axons (Nikić et al., 2011). The swollen axons in the EAE model last days instead of hours in the case of the contusion injury. Surprisingly, early stages of swollen axons could be observed without apparent myelin damage, indicating that axonal damage may precede myelin lesion in EAE. Additional experiments implicated the involvement of reactive oxygen and nitrogen species in FAD, as pharmacologically suppressing the reactive species with scavengers reduced axonal fragmentation (Nikić et al., 2011). Further, this study, together with work from Sadeghian et al. (2016), revealed mitochondrial damage as an early characteristic of axon damage in the inflamed spinal cord. This subcellular pathology was accompanied by loss of axonal transport of mitochondria and other organelles (Sorbara et al., 2014; Sadeghian et al., 2016). Therefore, just as with traumatic lesions, inflammatory diseases of the CNS also lead to a reversible state of axonal damage with a characteristic subcellular signature that can be rescued with pharmacological manipulations. Together, these studies point to the reversibility of axonal damage as a potential target to support therapeutically after CNS injury and disease (Nikić et al., 2011; Williams et al., 2014).

\section{In vivo imaging of substantial regrowth of serotonergic axons after brain damage}

In general, axons do not regenerate to a significant extent after injury in the CNS (Chew et al., 2012; Lu et al., 2014). However, there have been suggestions from studies in both injured brain and spinal cord (with or without a graft) that axons of serotonergic neurons might have an atypical capacity for regrowth (Lee et al., 2010; Alilain et al., 2011; Hawthorne et al., 2011; Kanno et al., 2014). It has been known for quite some time that, after a lesion of serotonergic axons in the rodent neocortex with a high dose of amphetamine, there is a gradual reappearance of serotonin (or 5-HT) immunoreactive axons over many months (Molliver et al., 1990; Mamounas et al., 2000). Although suggestive, these fixedtissue amphetamine studies were inconclusive: it was not possible to distinguish long-distance regrowth from local sprouting of surviving axons, nor was it possible to rule out the scenario that intact 5-HT axons were merely depleted of serotonin by amphetamine treatment and then slowly refilled. To disambiguate the results from fixed-tissue studies, Jin et al. (2016) performed in vivo two-photon time-lapse imaging of serotonergic axons over many months after damage (presented by D. Linden, 2017 SfN Mini-Symposium).

Using adult serotonin transporter-EGFP BAC transgenic mice (Gong et al., 2003), Jin et al. (2016) found that serotonin axons undergo widespread long-distance retrograde degeneration after amphetamine treatment and that the subsequent slow recovery of axonal density is dominated by long-distance regrowth with little contribution from local sprouting. The new, regrowing axons largely recapitulate the morphology (varicosity density, tortuosity), neighbor relations, and layer-specific distribution of prelesion axons. Unlike regrowing axons in the peripheral nervous system (Scheib and Höke, 2013), new serotonin axons do not follow the pathways left by degenerated axons. The new axons have normal varicosity density, longevity, and trajectories. They have the capacity to release serotonin, as measured by fast-scanning voltammetry, and their regeneration is correlated with recovery in behavioral tests. Furthermore, Jin et al. (2016) found that a stab injury that transects serotonin axons in the neocortex is followed by local regression of cut serotonin axons and by regrowth from the cut ends that can project across the glial scar which forms in the stab rift zone. Therefore, serotonin axons in the brain have an unusual capacity to regrow (Kajstura et al., 2017) and this regrowth is functional and approximates the prelesion state.

There are many important questions raised by these findings. For instance, what are the molecular specializations that distinguish serotonin axons from other CNS axons in their regenerative abilities? In addition, are all raphe serotonin neurons competent to regrow their axons or is this ability restricted to a particular anatomical or functional subset, for example, serotonin neurons that derive from embryonic rhombomere 1 (Jensen et al., 2008) or serotonin neurons that corelease glutamate, as was the case for retinal ganglion cells (Duan et al., 2015)?

\section{In vivo imaging of retinal axons and target neurons}

The optic nerve, the nerve bundle connecting the retina to the brain, comprises the axons of retinal ganglion cells which contain 
all the visual information that is available for object recognition. Restoring vision after optic nerve injuries such as brain trauma or glaucoma requires that the retinal axons regenerate, reach their appropriate brain targets, form functional synapses, and transmit information that supports a dynamic and detailed representation of the world. Although the mammalian optic nerve does not regenerate naturally, recent advances have been able to promote its regrowth over long distances, with some axons reaching normal brain targets and forming functional synapses by providing specific molecular therapies or selectively enhancing neural activity (Leaver et al., 2006; Moore et al., 2009; Sun et al., 2011; de Lima et al., 2012; Bei et al., 2016; Lim et al., 2016). Analogous to in vivo imaging paradigms described above for the spinal cord, in vivo imaging of the optic nerve in the proximity of nerve crush site close to the eye in anesthetized rodents provided mechanistic link between intra-axonal calcium, autophagy, and axonal degeneration (Knöferle et al., 2010; Koch et al., 2011).

One emerging challenge will be a direct assessment of the degree to which the visual representations of normal optic nerve inputs to brain targets is recapitulated after regeneration. Whether retinotopic map organization and visual tuning can be recovered after regeneration of a fraction of axons in the optic tract is not clear. Specific types of RGCs that show higher capabilities of regeneration may be overrepresented (Duan et al., 2015; Norsworthy et al., 2017). Visualization of regenerating RGC axons would permit discernment of how specific visual pathways or RGC subtypes contribute to functional regeneration. However, it has been difficult to measure structural changes and neural activity within RGCs and their target neurons in the intact visual system of awake animals.

M. Andermann and C. Chen and their colleagues have collaborated to develop in vivo methods that could, in future, allow monitoring of the natural progression of regenerating optic nerve and investigation of functional recovery in target areas such as the dorsal lateral geniculate nucleus ( $\mathrm{dLGN}$ ), a central relay station in the image formation pathway. Specifically, with the development of in vivo two-photon fluorescence imaging in dLGN of awake, head-fixed mice, Liang et al. could visualize the retinogeniculate synapse from the level of individual synaptic boutons to the level of large populations of cell bodies, and across multiple timescales, from milliseconds associated with electrical signaling to months over which plastic changes supporting functional regeneration occur (presented by L. Liang, 2017 SfN Mini-Symposium).

Chronic visualization of regenerating RGC axons could help us to understand the detailed dynamics that occur during rewiring. During normal development, axons undergo an intricate sequence including axon outgrowth, initial connections with target neurons, followed by refinement of axonal branches and boutons (Hong and Chen, 2011). Are these processes also occurring in regenerating axons? By comparing the dynamics of regenerating axons with the knowledge of normal RGC development and by comparing the behavior across axon growth induced through different molecular or activity models, it may be possible to identify roadblocks to axon regeneration and important attributes of each regeneration therapy. Moreover, chronic imaging will enable the evaluation of the degree of plasticity or stability of newly formed connections.

In addition, by imaging activity in large populations of regenerating axons and of second-order neurons in vivo, the above methodologies will allow assessment of the quality and quantity of visual information restoration in the target brain circuit. Liang et al. have begun to examine the neural activity transmitted in RGC axons by imaging calcium activity in the optic nerve and their terminals in the dLGN (Liang et al., 2017 SfN MiniSymposium). Although RGCs are composed of at least 30 distinct types, they can be well characterized by a few parameters: spatial receptive field preferences, orientation/direction selectivity, sensitivity to luminance changes, and spatiotemporal frequency preference (Farrow and Masland, 2011; Dhande et al., 2015; Sanes and Masland, 2015). Their studies of RGC axons from healthy mice reveal exquisite functional organization among axons carrying information regarding different visual features. These findings serve as a baseline to assess, in future, whether retinotopic map organization and visual tuning is restored in an orderly manner after regeneration.

\section{In vivo imaging of microglia and neurovascular unit in CNS disease and injury}

The ability to capture dynamic cellular interactions is especially warranted for research of neurological disorders typified by immune activation, vascular alterations, and neuronal dysfunction including Alzheimer's disease (AD) (Burgold et al., 2011; Sagare et al., 2013), multiple sclerosis (MS) (Davalos et al., 2012), and stroke (Lam et al., 2010; Knowland et al., 2014; Balbi et al., 2017). These disorders share a common hallmark of microglial activation and blood-brain barrier (BBB) disruption (Kwon and Prineas, 1994; Tomimoto et al., 1996; Cortes-Canteli et al., 2015). However, the sequence of events linking vascular changes and immune activation remain poorly understood.

Implementation of in vivo imaging techniques at the neurovascular interface has shed light onto the sequence of events and the causal relationships linking vascular, immune, and neuronal dysfunction in neurological diseases (Merlini et al., 2012; Akassoglou et al., 2016) (presented by K. Akassoglou, 2017 SfN Mini-Symposium). Development of methodologies to image simultaneously the vasculature with immune cells, glia, and neurons, not only in the brain but also the spinal cord, has been instrumental in understanding how changes in BBB permeability correlate with the development of neuroinflammation and neurologic diseases (Davalos et al., 2008; Davalos and Akassoglou, 2012b; Davalos et al., 2012; Merlini et al., 2012; Akassoglou et al., 2016). Coregistration of in vivo two-photon imaging data with correlative light-electron microscopy allowed unique insight into the cellular and molecular mechanisms identifying causal relationships among blood proteins, microglial activation, and axonal damage (Davalos et al., 2012). Development of a stable optical window in the mouse skull allowed repetitive imaging of microglia without causing brain inflammation (Drew et al., 2010). Molecular probes to detect coagulation activity in the CNS further provided tools for functional analysis of BBB disruption and neurovascular alterations (Davalos et al., 2014). These complementary tools enabled detailed image acquisition in vivo within a relatively small field of view and imaging of large tissue volumes ex vivo to reveal the distribution and scale of neuroinflammatory and neurodegenerative pathologies.

Studies using these tools to image the neurovascular interface revealed unanticipated mechanisms for the development of neuroinflammatory disease. They demonstrated perivascular microglia clustering at sites of BBB breakdown even before the onset of neurological symptoms in the murine MS model EAE (Davalos et al., 2012). Remarkably, microglial clustering was associated with BBB leakage and deposition of the blood coagulation factor fibrinogen in the CNS. Live imaging of BBB disruption identified focal extravasation of fibrinogen at sites of microglia clustering and axonal damage. Time-lapse imaging in the mouse cortex revealed rapid microglial responses to fibrinogen within minutes that were sustained for several hours after injection (Davalos et 
al., 2012). Imaging using a thrombin molecular probe revealed early increase of coagulation activity as one of the first signs in EAE correlating with microglia activation and fibrin deposition, but preceding demyelination (Davalos et al., 2014). Pharmacologic depletion of fibrinogen or genetic disruption of the interaction of fibrinogen with its CD11b/CD18 integrin receptor on microglia reduced perivascular microglial clustering, neurological signs, inflammatory responses, demyelination, and axonal damage in EAE (Adams et al., 2007; Davalos et al., 2012).

Studying the sequence of events in neuroinflammatory disease by in vivo two-photon microscopy led to the identification of $\mathrm{BBB}$ leakage and fibrin deposition as an early event preceding microglial activation and demyelination. To test whether fibrinogen was sufficient to induce these pathologies, fibrinogen was stereotactically injected in the healthy CNS. Fibrinogen injection in the corpus callosum stimulated macrophage recruitment, antigen presentation, and activation of myelin antigen-specific Th1 cells leading to demyelination (Ryu et al., 2015). Fibrinogeninduced encephalomyelitis could represent a novel experimental setting for the study of vascular-driven, innate-immune mediated neuroinflammation. Together, these studies highlight how integration of in vivo imaging of the neurovascular interface may reveal the sequence of events that leads to neurologic impairment. Therefore, in vivo imaging is critical for the identification of molecular pathways apical to disease pathogenesis and prioritization of further testing of their potential causal role for immune and neurodegenerative mechanisms in the CNS. Using in vivo imaging in animal models of neuroimmunology and neurovascular dysfunction provides invaluable insight for the identification of molecular targets that could be instrumental for the development of novel therapeutic strategies, imaging probes, animal models, and biomarkers for disease onset and progression (Adams et al., 2007; Davalos and Akassoglou, 2012a; Davalos et al., 2012; Bardehle et al., 2015; Ryu et al., 2015).

\section{In vivo structural and functional imaging of transplanted human induced pluripotent stem cell (iPSC)-derived neurons}

In vivo optical imaging has revolutionized the study of synaptic connectivity in cortical circuits, providing invaluable insights into the role of synaptic rewiring in learning and memory (Holtmaat and Caroni, 2016), aging (Grillo et al., 2013; Mostany et al., 2013), and after injury (Allegra Mascaro et al., 2013; Canty et al., 2013a, b) and disease (Cruz-Martín et al., 2010; Murmu et al., 2013; Holtmaat and Caroni, 2016; Jackson et al., 2017). Many fundamental questions regarding the biology of neural connectivity have, until recently, been restricted to nonhuman models. For example, it is not known whether and how human neurons undergo synaptic rewiring in mature functional networks. Equally unclear is how to best model the many human diseases affecting synaptic connectivity, which include neurodevelopmental, psychiatric, and neurodegenerative diseases. In vivo optical imaging of human-derived neurons is likely to play a pivotal role in addressing these outstanding issues.

The in vitro generation of neurons differentiated from human embryonic stem cells (ESCs) or iPSCs has emerged as a promising tool with which to model the assembly of synaptic networks in human brain development and diseases (Brennand et al., 2011; Shcheglovitov et al., 2013; Wen et al., 2014). However, cultures of ESC/iPSC-derived neurons, including cerebral organoids (Lancaster et al., 2013), lack vasculature and other key regulatory signals and are therefore limited by short-term survival and incomplete neuronal and synaptic maturation (Kim et al., 2011; Thompson and Björklund, 2015; Korecka et al., 2016). The trans- plantation of human ESC/iPSC-derived neurons in the CNS of rodents (also called chimeric human-rodent models) enhances the survival and functional maturation of human neurons (EspunyCamacho et al., 2013; Korecka et al., 2016; Niclis et al., 2017) and substantial efforts are under way to fully elucidate whether and how human ESC/iPSC-derived neurons can form synapses and functionally integrate into the host neural circuitry. Two major prospects of such humanized rodent systems are the improvement of cell replacement therapy, for example, for stroke or brain injury, and more accurate disease modeling than possible with current animal studies.

Although transplanted human PSC-derived neurons could promote the functional recovery of damaged circuits through various mechanisms, including neuroprotection and stimulation of host plasticity, several groups have investigated host-to-graft functional connectivity through different strategies (Lindvall and Kokaia, 2010; Lu et al., 2012; Byers et al., 2015; Thompson and Björklund, 2015). In a recent study, mouse embryonic neurons were transplanted in the primary visual cortex of adult mice after selective ablation of neurons in the same area (Falkner et al., 2016). As shown previously (Michelsen et al., 2015), transplanted neurons extended axons and received input from host neurons in a target-specific manner. More importantly, by labeling the transplanted neurons with a genetically encoded calcium indicator and performing in vivo imaging of stimulus-evoked responses, Falkner et al. (2016) demonstrated that transplanted neurons respond to visual stimuli in a manner indistinguishable from the host neurons, indicating full integration within the host visual circuitry. However, whether transplanted human ESC/iPSC-derived neurons have similar dynamics of integration as transplanted embryonic neurons and their mechanisms of integration remain unknown.

Interestingly, human iPSC-derived neurons transplanted in the cortex of adult rats after distal middle cerebral artery occlusion receive functional synaptic input from the host, as evidenced by the presence of optogenetic and sensory stimulation-elicited electrophysiological responses in the transplanted human neurons (Tornero et al., 2017). In collaboration with Dr. Rick Livesey (University of Cambridge, Cambridge, UK), Real and De Paola (presented by V. De Paola, 2017 SfN Mini-Symposium) have recently used longitudinal structural and functional multiphoton imaging correlated with electron microscopy, combined with rabies tracing, electrophysiology, and molecular analyses to characterize the dynamics of transplanted human neurons for periods of up to 6 months. They show that transplanted human iPSC-derived neurons of cortical identity form an interconnected circuit that receives input from the host and undergoes functional synaptic rewiring.

Animal models of complex neurological diseases often do not recapitulate the full extent of human phenotypes. The generation of chimeric human-rodent models of neurological diseases is thus a step forward, providing a valuable tool to investigate human-specific phenotypes and disease mechanisms. A possible approach is to transplant human ESC/iPSC-derived neurons from healthy individuals into animal models of disease. In a recent study, the transplantation of healthy human ESC-derived neurons in a well characterized mouse model of $\mathrm{AD}$ led to the development of $\mathrm{AD}$ pathology in the human graft, including neuronal loss and the appearance of pathological tau species, features not observed in the host brain (Espuny-Camacho et al., 2017). An alternative approach is the use of iPSC-derived neurons from patients with specific neurological disorders, which provides insights into the cell-autonomous factors contributing to disease phenotypes. This approach is especially relevant to uncover neuronal maturation defects as well as synaptic and neural circuitry dysfunction. In this context, the use of in vivo synaptic and calcium imaging 
can elucidate cellular and network connectivity phenotypes, helping us to understand the mechanisms underlying complex human brain diseases in ways not previously possible. Using this new system, De Paola and colleagues were able to show that neurons from patients with Down's syndrome fail to synchronize network activity in vivo (presented by V. De Paola, 2017 SfN Mini-Symposium).

\section{Concluding remarks}

In conclusion, as discussed here and at the 2017 SfN MiniSymposium, in vivo optical imaging has revealed fundamental new insights on neuronal, glial, immune, vascular, and other cellular responses to injury and disease in the mammalian CNS. Just as 3D imaging of cleared tissue blocks addresses the spatial complexity of the CNS (Chung et al., 2013), in vivo time-lapse imaging tackles the temporal complexity. As with many other areas in modern biology, we anticipate that technological advances will continue to serve as a driver for research progress, in particularly where in vivo imaging intersects with other emerging tools and technologies. Methods to facilitate repetitive in vivo imaging across chronic time points (Drew et al., 2010; Farrar et al., 2012; Fenrich et al., 2012), to image freely behaving mice (Sekiguchi et al., 2016), and to image more deeply into the brain (Ouzounov et al., 2017) are opening new frontiers of investigation. The availability of genetically encoded calcium and voltage indicators (Lin and Schnitzer, 2016) allows for in vivo imaging of neuronal activity; monitoring activity in single axons, however, still remains an unmet challenge. New biosensors that monitor metabolic parameters in neurons (Breckwoldt et al., 2014; Mächler et al., 2016; Trevisiol et al., 2017) will add further functional dimensions to in vivo imaging. By integrating structural and functional investigation in conjunction with methods to monitor and manipulate neuronal activity (Kim et al., 2017) and glial-neuron interatctions (Akassoglou et al., 2016), in vivo optical imaging will continue to enable new discoveries. Molecular information revealed by multiomics approaches can be used for the discovery and generation of novel molecular probes to detect neuronal dysfunction, immune cell activation, and vascular abnormalities. These approaches have the potential to uncover new avenues for therapeutic intervention in neurological diseases.

The latter is especially important given the gap between successful drug discovery for CNS diseases and breakthroughs in the discovery of mechanisms underlying disease pathogenesis. In vivo optical imaging is ideally positioned to bridge this translational gap. First, in vivo two-photon imaging allows the study of the sequence of events that lead to neurological disease, thus revealing the early triggers and apical mechanisms responsible for disease pathogenesis. Identifying how disease starts is critical for drug discovery because it allows the prioritization of drug targets. Second, the versatility of in vivo two-photon imaging in bringing to light various acute and chronic (patho)physiological phenomena allows direct comparisons with findings from widely used clinical imaging modalities such as functional magnetic resonance imaging (fMRI), magnetic resonance spectroscopy (MRS), and positron-emission tomography. An example of the strength of such interchangeable, translational imaging studies is longitudinal in vivo two-photon imaging of altered cerebral blood flow and brain metabolism at early and late disease stages in rodent models of neurological disease (San Martín et al., 2014; Stuntz et al., 2017). The results of these can provide unprecedented, highresolution cellular insight into the mechanisms underlying similar changes in humans as measured by fMRI and MRS (Borsook et al., 2006; Modrego et al., 2011). Finally, in vivo two-photon imaging can be used to develop rapid pharmacodynamics models to accelerate drug discovery. For example, drug delivery through a thinned skull and study of microglia responses using in vivo two-photon imaging allows assessment of drug compounds within $24 \mathrm{~h}$ after traumatic brain injury (Roth et al., 2014). Therefore, in vivo optical imaging can critically contribute to translational efforts to combat neurological disease by identifying the sequence of events that triggers and propagates CNS disease, facilitating the development of molecular probes and accelerating drug discovery.

\section{References}

Adams RA, Bauer J, Flick MJ, Sikorski SL, Nuriel T, Lassmann H, Degen JL, Akassoglou K (2007) The fibrin-derived gamma377-395 peptide inhibits microglia activation and suppresses relapsing paralysis in central nervous system autoimmune disease. J Exp Med 204:571-582. CrossRef Medline

Akassoglou K, Agalliu D, Chang CJ, Davalos D, Grutzendler J, Hillman EM, Khakh BS, Kleinfeld D, McGavern DB, Nelson SJ, Zlokovic BV (2016) Neurovascular and immuno-imaging: from mechanisms to therapies. proceedings of the inaugural symposium. Front Neurosci 10:46. CrossRef Medline

Alilain WJ, Horn KP, Hu H, Dick TE, Silver J (2011) Functional regeneration of respiratory pathways after spinal cord injury. Nature 475:196-200. CrossRef Medline

Allegra Mascaro AL, Cesare P, Sacconi L, Grasselli G, Mandolesi G, Maco B, Knott GW, Huang L, De Paola V, Strata P, Pavone FS (2013) In vivo single branch axotomy induces GAP-43-dependent sprouting and synaptic remodeling in cerebellar cortex. Proc Natl Acad Sci U S A 110:1082410829. CrossRef Medline

Balbi M, Vanni MP, Silasi G, Sekino Y, Bolanos L, LeDue JM, Murphy TH (2017) Targeted ischemic stroke induction and mesoscopic imaging assessment of blood flow and ischemic depolarization in awake mice. Neurophotonics 4:035001. CrossRef Medline

Bardehle S, Rafalski VA, Akassoglou K (2015) Breaking boundariescoagulation and fibrinolysis at the neurovascular interface. Front Cell Neurosci 9:354. CrossRef Medline

Bareyre FM, Garzorz N, Lang C, Misgeld T, Büning H, Kerschensteiner M (2011) In vivo imaging reveals a phase-specific role of STAT3 during central and peripheral nervous system axon regeneration. Proc Natl Acad Sci U S A 108:6282-6287. CrossRef Medline

Bei F, Lee HHC, Liu X, Gunner G, Jin H, Ma L, Wang C, Hou L, Hensch TK, Frank E, Sanes JR, Chen C, Fagiolini M, He Z (2016) Restoration of visual function by enhancing conduction in regenerated axons. Cell 164 : 219-232. CrossRef Medline

Bishop D, Nikić I, Brinkoetter M, Knecht S, Potz S, Kerschensteiner M, Misgeld T (2011) Near-infrared branding efficiently correlates light and electron microscopy. Nat Methods 8:568-570. CrossRef Medline

Borsook D, Becerra L, Hargreaves R (2006) A role for fMRI in optimizing CNS drug development. Nat Rev Drug Discov 5:411-424. CrossRef Medline

Breckwoldt MO, Pfister FM, Bradley PM, Marinkovic P, Williams PR, Brill MS, Plomer B, Schmalz A, St Clair DK, Naumann R, Griesbeck O, Schwarzländer M, Godinho L, Bareyre FM, Dick TP, Kerschensteiner M, Misgeld T (2014) Multiparametric optical analysis of mitochondrial redox signals during neuronal physiology and pathology in vivo. Nat Med 20:555-560. CrossRef Medline

Brennand KJ, Simone A, Jou J, Gelboin-Burkhart C, Tran N, Sangar S, Li Y, Mu Y, Chen G, Yu D, McCarthy S, Sebat J, Gage FH (2011) Modelling schizophrenia using human induced pluripotent stem cells. Nature 473: 221-225. CrossRef Medline

Burgold S, Bittner T, Dorostkar MM, Kieser D, Fuhrmann M, Mitteregger G, Kretzschmar H, Schmidt B, Herms J (2011) In vivo multiphoton imaging reveals gradual growth of newborn amyloid plaques over weeks. Acta Neuropathol 121:327-335. CrossRef Medline

Byers B, Lee HJ, Liu J, Weitz AJ, Lin P, Zhang P, Shcheglovitov A, Dolmetsch R, Pera RR, Lee JH (2015) Direct in vivo assessment of human stem cell graft-host neural circuits. Neuroimage 114:328-337. CrossRef Medline

Canty AJ, Teles-Grilo Ruivo LM, Nesarajah C, Song S, Jackson JS, Little GE, De Paola V (2013a) Synaptic elimination and protection after minimal injury depend on cell type and their prelesion structural dynamics in the adult cerebral cortex. J Neurosci 33:10374-10383. CrossRef Medline 
Canty AJ, Huang L, Jackson JS, Little GE, Knott G, Maco B, De Paola V (2013b) In-vivo single neuron axotomy triggers axon regeneration to restore synaptic density in specific cortical circuits. Nat Commun 4:2038. CrossRef Medline

Chen M, Zheng B (2014) Axon plasticity in the mammalian central nervous system after injury. Trends Neurosci 37:583-593. CrossRef Medline

Chew DJ, Fawcett JW, Andrews MR (2012) The challenges of long-distance axon regeneration in the injured CNS. Prog Brain Res 201:253-294. CrossRef Medline

Chung K, Wallace J, Kim SY, Kalyanasundaram S, Andalman AS, Davidson TJ, Mirzabekov JJ, Zalocusky KA, Mattis J, Denisin AK, Pak S, Bernstein H, Ramakrishnan C, Grosenick L, Gradinaru V, Deisseroth K (2013) Structural and molecular interrogation of intact biological systems. Nature 497:332-337. CrossRef Medline

Cortes-Canteli M, Mattei L, Richards AT, Norris EH, Strickland S (2015) Fibrin deposited in the Alzheimer's disease brain promotes neuronal degeneration. Neurobiol Aging 36:608-617. CrossRef Medline

Cruz-Martín A, Crespo M, Portera-Cailliau C (2010) Delayed stabilization of dendritic spines in fragile X mice. J Neurosci 30:7793-7803. CrossRef Medline

Davalos D, Akassoglou K (2012a) Fibrinogen as a key regulator of inflammation in disease. Semin Immunopathol 34:43-62. CrossRef Medline

Davalos D, Akassoglou K (2012b) In vivo imaging of the mouse spinal cord using two-photon microscopy. J Vis Exp 59:e2760. CrossRef Medline

Davalos D, Lee JK, Smith WB, Brinkman B, Ellisman MH, Zheng B, Akassoglou K (2008) Stable in vivo imaging of densely populated glia, axons and blood vessels in the mouse spinal cord using two-photon microscopy. J Neurosci Methods 169:1-7. CrossRef Medline

Davalos D, Ryu JK, Merlini M, Baeten KM, Le Moan N, Petersen MA, Deerinck TJ, Smirnoff DS, Bedard C, Hakozaki H, Gonias Murray S, Ling JB, Lassmann H, Degen JL, Ellisman MH, Akassoglou K (2012) Fibrinogeninduced perivascular microglial clustering is required for the development of axonal damage in neuroinflammation. Nat Commun 3:1227. CrossRef Medline

Davalos D, Baeten KM, Whitney MA, Mullins ES, Friedman B, Olson ES, Ryu JK, Smirnoff DS, Petersen MA, Bedard C, Degen JL, Tsien RY, Akassoglou K (2014) Early detection of thrombin activity in neuroinflammatory disease. Ann Neurol 75:303-308. CrossRef Medline

de Lima S, Koriyama Y, Kurimoto T, Oliveira JT, Yin Y, Li Y, Gilbert HY, Fagiolini M, Martinez AM, Benowitz L (2012) Full-length axon regeneration in the adult mouse optic nerve and partial recovery of simple visual behaviors. Proc Natl Acad Sci U S A 109:9149-9154. CrossRef Medline

Denk W, Strickler JH, Webb WW (1990) Two-photon laser scanning fluorescence microscopy. Science 248:73-76. CrossRef Medline

Dhande OS, Stafford BK, Lim JA, Huberman AD (2015) Contributions of retinal ganglion cells to subcortical visual processing and behaviors. Annu Rev Vis Sci 1:291-328. CrossRef Medline

Di Maio A, Skuba A, Himes BT, Bhagat SL, Hyun JK, Tessler A, Bishop D, Son YJ (2011) In vivo imaging of dorsal root regeneration: rapid immobilization and presynaptic differentiation at the CNS/PNS border. J Neurosci 31:4569-4582. CrossRef Medline

Dray C, Rougon G, Debarbieux F (2009) Quantitative analysis by in vivo imaging of the dynamics of vascular and axonal networks in injured mouse spinal cord. Proc Natl Acad Sci U S A 106:9459-9464. CrossRef Medline

Drew PJ, Shih AY, Driscoll JD, Knutsen PM, Blinder P, Davalos D, Akassoglou K, Tsai PS, Kleinfeld D (2010) Chronic optical access through a polished and reinforced thinned skull. Nat Methods 7:981-984. CrossRef Medline

Duan X, Qiao M, Bei F, Kim IJ, He Z, Sanes JR (2015) Subtype-specific regeneration of retinal ganglion cells following axotomy: effects of osteopontin and mTOR signaling. Neuron 85:1244-1256. CrossRef Medline

Ertürk A, Hellal F, Enes J, Bradke F (2007) Disorganized microtubules underlie the formation of retraction bulbs and the failure of axonal regeneration. J Neurosci 27:9169-9180. CrossRef Medline

Espuny-Camacho I, Michelsen KA, Gall D, Linaro D, Hasche A, Bonnefont J, Bali C, Orduz D, Bilheu A, Herpoel A, Lambert N, Gaspard N, Péron S, Schiffmann SN, Giugliano M, Gaillard A, Vanderhaeghen P (2013) Pyramidal neurons derived from human pluripotent stem cells integrate efficiently into mouse brain circuits in vivo. Neuron 77:440-456. CrossRef Medline
Espuny-Camacho I, Arranz AM, Fiers M, Snellinx A, Ando K, Munck S, Bonnefont J, Lambot L, Corthout N, Omodho L, Vanden Eynden E, Radaelli E, Tesseur I, Wray S, Ebneth A, Hardy J, Leroy K, Brion JP, Vanderhaeghen P, De Strooper B (2017) Hallmarks of Alzheimer's disease in stem-cell-derived human neurons transplanted into mouse brain. Neuron 93:1066-1081 e1068. CrossRef Medline

Evans TA, Barkauskas DS, Myers JT, Hare EG, You JQ, Ransohoff RM, Huang AY, Silver J (2014) High-resolution intravital imaging reveals that blood-derived macrophages but not resident microglia facilitate secondary axonal dieback in traumatic spinal cord injury. Exp Neurol 254:109120. CrossRef Medline

Falkner S, Grade S, Dimou L, Conzelmann KK, Bonhoeffer T, Götz M, Hübener M (2016) Transplanted embryonic neurons integrate into adult neocortical circuits. Nature 539:248-253. CrossRef Medline

Farrar MJ, Bernstein IM, Schlafer DH, Cleland TA, Fetcho JR, Schaffer CB (2012) Chronic in vivo imaging in the mouse spinal cord using an implanted chamber. Nat Methods 9:297-302. CrossRef Medline

Farrow K, Masland RH (2011) Physiological clustering of visual channels in the mouse retina. J Neurophysiol 105:1516-1530. CrossRef Medline

Feng G, Mellor RH, Bernstein M, Keller-Peck C, Nguyen QT, Wallace M, Nerbonne JM, Lichtman JW, Sanes JR (2000) Imaging neuronal subsets in transgenic mice expressing multiple spectral variants of GFP. Neuron 28:41-51. CrossRef Medline

Fenrich KK, Weber P, Hocine M, Zalc M, Rougon G, Debarbieux F (2012) Long-term in vivo imaging of normal and pathological mouse spinal cord with subcellular resolution using implanted glass windows. J Physiol 590: 3665-3675. CrossRef Medline

Geoffroy CG, Zheng B (2014) Myelin-associated inhibitors in axonal growth after CNS injury. Curr Opin Neurobiol 27:31-38. CrossRef Medline

Gong S, Zheng C, Doughty ML, Losos K, Didkovsky N, Schambra UB, Nowak NJ, Joyner A, Leblanc G, Hatten ME, Heintz N (2003) A gene expression atlas of the central nervous system based on bacterial artificial chromosomes. Nature 425:917-925. CrossRef Medline

Grillo FW, Song S, Teles-Grilo Ruivo LM, Huang L, Gao G, Knott GW, Maco B, Ferretti V, Thompson D, Little GE, De Paola V (2013) Increased axonal bouton dynamics in the aging mouse cortex. Proc Natl Acad Sci U S A 110:E1514-E1523. CrossRef Medline

Hawthorne AL, Hu H, Kundu B, Steinmetz MP, Wylie CJ, Deneris ES, Silver J (2011) The unusual response of serotonergic neurons after CNS Injury: lack of axonal dieback and enhanced sprouting within the inhibitory environment of the glial scar. J Neurosci 31:5605-5616. CrossRef Medline

Holtmaat A, Caroni P (2016) Functional and structural underpinnings of neuronal assembly formation in learning. Nat Neurosci 19:1553-1562. CrossRef Medline

Hong YK, Chen C (2011) Wiring and rewiring of the retinogeniculate synapse. Curr Opin Neurobiol 21:228-237. CrossRef Medline

Jackson JS, Witton J, Johnson JD, Ahmed Z, Ward M, Randall AD, Hutton ML, Isaac JT, O'Neill MJ, Ashby MC (2017) Altered synapse stability in the early stages of tauopathy. Cell Rep 18:3063-3068. CrossRef Medline

Jensen P, Farago AF, Awatramani RB, Scott MM, Deneris ES, Dymecki SM (2008) Redefining the serotonergic system by genetic lineage. Nat Neurosci 11:417-419. CrossRef Medline

Jin Y, Dougherty SE, Wood K, Sun L, Cudmore RH, Abdalla A, Kannan G, Pletnikov M, Hashemi P, Linden DJ (2016) Regrowth of serotonin axons in the adult mouse brain following injury. Neuron 91:748-762. CrossRef Medline

Kajstura TJ, Dougherty SE, Linden DJ (2017) Serotonin axons in the neocortex of the adult female mouse regrow after traumatic brain injury. J Neurosci Res. Advance online publication. Retrieved October 19, 2017. doi:10.1002/jnr.24059.

Kanno H, Pressman Y, Moody A, Berg R, Muir EM, Rogers JH, Ozawa H, Itoi E, Pearse DD, Bunge MB (2014) Combination of engineered Schwann cell grafts to secrete neurotrophin and chondroitinase promotes axonal regeneration and locomotion after spinal cord injury. J Neurosci 34: 1838-1855. CrossRef Medline

Kerschensteiner M, Schwab ME, Lichtman JW, Misgeld T (2005) In vivo imaging of axonal degeneration and regeneration in the injured spinal cord. Nat Med 11:572-577. CrossRef Medline

Kim CK, Adhikari A, Deisseroth K (2017) Integration of optogenetics with complementary methodologies in systems neuroscience. Nat Rev Neurosci 18:222-235. CrossRef Medline

Kim JE, O'Sullivan ML, Sanchez CA, Hwang M, Israel MA, Brennand K, 
Deerinck TJ, Goldstein LS, Gage FH, Ellisman MH, Ghosh A (2011) Investigating synapse formation and function using human pluripotent stem cell-derived neurons. Proc Natl Acad Sci U S A 108:3005-3010. CrossRef Medline

Knöferle J, Koch JC, Ostendorf T, Michel U, Planchamp V, Vutova P, Tönges L, Stadelmann C, Brück W, Bähr M, Lingor P (2010) Mechanisms of acute axonal degeneration in the optic nerve in vivo. Proc Natl Acad Sci U S A 107:6064-6069. CrossRef Medline

Knowland D, Arac A, Sekiguchi KJ, Hsu M, Lutz SE, Perrino J, Steinberg GK, Barres BA, Nimmerjahn A, Agalliu D (2014) Stepwise recruitment of transcellular and paracellular pathways underlies blood-brain barrier breakdown in stroke. Neuron 82:603-617. CrossRef Medline

Koch JC, Knöferle J, Tönges L, Michel U, Bähr M, Lingor P (2011) Imaging of rat optic nerve axons in vivo. Nat Protoc 6:1887-1896. CrossRef Medline

Korecka JA, Levy S, Isacson O (2016) In vivo modeling of neuronal function, axonal impairment and connectivity in neurodegenerative and neuropsychiatric disorders using induced pluripotent stem cells. Mol Cell Neurosci 73:3-12. CrossRef Medline

Kwon EE, Prineas JW (1994) Blood-brain barrier abnormalities in longstanding multiple sclerosis lesions: an immunohistochemical study. J Neuropathol Exp Neurol 53:625-636. CrossRef Medline

Lam CK, Yoo T, Hiner B, Liu Z, Grutzendler J (2010) Embolus extravasation is an alternative mechanism for cerebral microvascular recanalization. Nature 465:478-482. CrossRef Medline

Lancaster MA, Renner M, Martin CA, Wenzel D, Bicknell LS, Hurles ME, Homfray T, Penninger JM, Jackson AP, Knoblich JA (2013) Cerebral organoids model human brain development and microcephaly. Nature 501:373-379. CrossRef Medline

Leaver SG, Cui Q, Plant GW, Arulpragasam A, Hisheh S, Verhaagen J, Harvey AR (2006) AAV-mediated expression of CNTF promotes long-term survival and regeneration of adult rat retinal ganglion cells. Gene Ther 13:1328-1341. CrossRef Medline

Lee JK, Chow R, Xie F, Chow SY, Tolentino KE, Zheng B (2010) Combined genetic attenuation of myelin and Semaphorin-mediated growth inhibition is insufficient to promote serotonergic axon regeneration. J Neurosci 30:10899-10904. CrossRef Medline

Lim JH, Stafford BK, Nguyen PL, Lien BV, Wang C, Zukor K, He Z, Huberman AD (2016) Neural activity promotes long-distance, target-specific regeneration of adult retinal axons. Nat Neurosci 19:1073-1084. CrossRef Medline

Lin MZ, Schnitzer MJ (2016) Genetically encoded indicators of neuronal activity. Nat Neurosci 19:1142-1153. CrossRef Medline

Lindvall O, Kokaia Z (2010) Stem cells in human neurodegenerative disorders-time for clinical translation? J Clin Invest 120:29-40. CrossRef Medline

Lorenzana AO, Lee JK, Mui M, Chang A, Zheng B (2015) A surviving intact branch stabilizes remaining axon architecture after injury as revealed by in vivo imaging in the mouse spinal cord. Neuron 86:947-954. CrossRef Medline

Lu P, Wang Y, Graham L, McHale K, Gao M, Wu D, Brock J, Blesch A, Rosenzweig ES, Havton LA, Zheng B, Conner JM, Marsala M, Tuszynski MH (2012) Long-distance growth and connectivity of neural stem cells after severe spinal cord injury. Cell 150:1264-1273. CrossRef Medline

Lu Y, Belin S, He Z (2014) Signaling regulations of neuronal regenerative ability. Curr Opin Neurobiol 27:135-142. CrossRef Medline

Mächler P, Wyss MT, Elsayed M, Stobart J, Gutierrez R, von Faber-Castell A, Kaelin V, Zuend M, San Martín A, Romero-Gómez I, Baeza-Lehnert F, Lengacher S, Schneider BL, Aebischer P, Magistretti PJ, Barros LF, Weber B (2016) In vivo evidence for a lactate gradient from astrocytes to neurons. Cell Metab 23:94-102. CrossRef Medline

Mamounas LA, Altar CA, Blue ME, Kaplan DR, Tessarollo L, Lyons WE (2000) BDNF promotes the regenerative sprouting, but not survival, of injured serotonergic axons in the adult rat brain. J Neurosci 20:771-782. Medline

Merlini M, Davalos D, Akassoglou K (2012) In vivo imaging of the neurovascular unit in CNS disease. Intravital 1:87-94. CrossRef Medline

Michelsen KA, Acosta-Verdugo S, Benoit-Marand M, Espuny-Camacho I, Gaspard N, Saha B, Gaillard A, Vanderhaeghen P (2015) Area-specific reestablishment of damaged circuits in the adult cerebral cortex by cortical neurons derived from mouse embryonic stem cells. Neuron 85:982997. CrossRef Medline

Misgeld T, Kerschensteiner M (2006) In vivo imaging of the diseased nervous system. Nat Rev Neurosci 7:449-463. Medline
Modrego PJ, Fayed N, Sarasa M (2011) Magnetic resonance spectroscopy in the prediction of early conversion from amnestic mild cognitive impairment to dementia: a prospective cohort study. BMJ Open 1:e000007. CrossRef Medline

Molliver ME, Berger UV, Mamounas LA, Molliver DC, O’Hearn E, Wilson MA (1990) Neurotoxicity of MDMA and related compounds: anatomic studies. Ann N Y Acad Sci 600:649-661; discussion 661-664. Medline

Moore DL, Blackmore MG, Hu Y, Kaestner KH, Bixby JL, Lemmon VP, Goldberg JL (2009) KLF family members regulate intrinsic axon regeneration ability. Science 326:298-301. CrossRef Medline

Mostany R, Anstey JE, Crump KL, Maco B, Knott G, Portera-Cailliau C (2013) Altered synaptic dynamics during normal brain aging. J Neurosci 33:4094-4104. CrossRef Medline

Murmu RP, Li W, Holtmaat A, Li JY (2013) Dendritic spine instability leads to progressive neocortical spine loss in a mouse model of Huntington's disease. J Neurosci 33:12997-13009. CrossRef Medline

Niclis JC, Turner C, Durnall J, McDougal S, Kauhausen JA, Leaw B, Dottori M, Parish CL, Thompson LH (2017) Long-distance axonal growth and protracted functional maturation of neurons derived from human induced pluripotent stem cells after intracerebral transplantation. Stem Cells Transl Med 6:1547-1556. CrossRef Medline

Nikić I, Merkler D, Sorbara C, Brinkoetter M, Kreutzfeldt M, Bareyre FM, Brück W, Bishop D, Misgeld T, Kerschensteiner M (2011) A reversible form of axon damage in experimental autoimmune encephalomyelitis and multiple sclerosis. Nat Med 17:495-499. CrossRef Medline

Norsworthy MW, Bei F, Kawaguchi R, Wang Q, Tran NM, Li Y, Brommer B, Zhang Y, Wang C, Sanes JR, Coppola G, He Z (2017) Sox11 expression promotes regeneration of some retinal ganglion cell types but kills others. Neuron 94:1112-1120.e4. CrossRef Medline

Ouzounov DG, Wang T, Wang M, Feng DD, Horton NG, Cruz-Hernández JC, Cheng YT, Reimer J, Tolias AS, Nishimura N, Xu C (2017) In vivo three-photon imaging of activity of GCaMP6-labeled neurons deep in intact mouse brain. Nat Methods 14:388-390. CrossRef Medline

Roth TL, Nayak D, Atanasijevic T, Koretsky AP, Latour LL, McGavern DB (2014) Transcranial amelioration of inflammation and cell death after brain injury. Nature 505:223-228. CrossRef Medline

Ryu JK, Petersen MA, Murray SG, Baeten KM, Meyer-Franke A, Chan JP, Vagena E, Bedard C, Machado MR, Rios Coronado PE, Prod'homme T, Charo IF, Lassmann H, Degen JL, Zamvil SS, Akassoglou K (2015) Blood coagulation protein fibrinogen promotes autoimmunity and demyelination via chemokine release and antigen presentation. Nat Commun 6:8164. CrossRef Medline

Sadeghian M, Mastrolia V, Rezaei Haddad A, Mosley A, Mullali G, Schiza D, Sajic M, Hargreaves I, Heales S, Duchen MR, Smith KJ (2016) Mitochondrial dysfunction is an important cause of neurological deficits in an inflammatory model of multiple sclerosis. Sci Rep 6:33249. CrossRef Medline

Sagare AP, Bell RD, Zhao Z, Ma Q, Winkler EA, Ramanathan A, Zlokovic BV (2013) Pericyte loss influences Alzheimer-like neurodegeneration in mice. Nat Commun 4:2932. CrossRef Medline

San Martín A, Sotelo-Hitschfeld T, Lerchundi R, Fernández-Moncada I, Ceballo S, Valdebenito R, Baeza-Lehnert F, Alegría K, Contreras-Baeza Y, Garrido-Gerter P, Romero-Gómez I, Barros LF (2014) Single-cell imaging tools for brain energy metabolism: a review. Neurophotonics 1:011004. CrossRef Medline

Sanes JR, Masland RH (2015) The types of retinal ganglion cells: current status and implications for neuronal classification. Annu Rev Neurosci 38:221-246. CrossRef Medline

Scheib J, Höke A (2013) Advances in peripheral nerve regeneration. Nat Rev Neurol 9:668-676. CrossRef Medline

Sekiguchi KJ, Shekhtmeyster P, Merten K, Arena A, Cook D, Hoffman E, Ngo A, Nimmerjahn A (2016) Imaging large-scale cellular activity in spinal cord of freely behaving mice. Nat Commun 7:11450. CrossRef Medline

Shcheglovitov A, Shcheglovitova O, Yazawa M, Portmann T, Shu R, Sebastiano V, Krawisz A, Froehlich W, Bernstein JA, Hallmayer JF, Dolmetsch RE (2013) SHANK3 and IGF1 restore synaptic deficits in neurons from 22q13 deletion syndrome patients. Nature 503:267-271. CrossRef Medline

Sorbara CD, Wagner NE, Ladwig A, Nikić I, Merkler D, Kleele T, Marinković P, Naumann R, Godinho L, Bareyre FM, Bishop D, Misgeld T, Kerschensteiner M (2014) Pervasive axonal transport deficits in multiple sclerosis models. Neuron 84:1183-1190. CrossRef Medline

Stuntz E, Gong Y, Sood D, Liaudanskaya V, Pouli D, Quinn KP, Alonzo C, Liu 
Z, Kaplan DL, Georgakoudi I (2017) Endogenous two-photon excited fluorescence imaging characterizes neuron and astrocyte metabolic responses to manganese toxicity. Sci Rep 7:1041. CrossRef Medline

Sun F, Park KK, Belin S, Wang D, Lu T, Chen G, Zhang K, Yeung C, Feng G, Yankner BA, He Z (2011) Sustained axon regeneration induced by co-deletion of PTEN and SOCS3. Nature 480:372-375. CrossRef Medline

Thompson LH, Björklund A (2015) Reconstruction of brain circuitry by neural transplants generated from pluripotent stem cells. Neurobiol Dis 79:28-40. CrossRef Medline

Tomimoto H, Akiguchi I, Suenaga T, Nishimura M, Wakita H, Nakamura S, Kimura J (1996) Alterations of the blood-brain barrier and glial cells in white-matter lesions in cerebrovascular and Alzheimer's disease patients. Stroke 27:2069-2074. CrossRef Medline

Tornero D, Tsupykov O, Granmo M, Rodriguez C, Grønning-Hansen M, Thelin J, Smozhanik E, Laterza C, Wattananit S, Ge R, Tatarishvili J, Grealish S, Brustle O, Skibo G, Parmar M, Schouenborg J, Lindvall O,
Kokaia Z (2017) Synaptic inputs from stroke-injured brain to grafted human stem cell-derived neurons activated by sensory stimuli. Brain 140: 692-706. Medline

Trevisiol A, Saab AS, Winkler U, Marx G, Imamura H, Mobius W, Kusch K Nave KA, Hirrlinger J (2017) Monitoring ATP dynamics in electrically active white matter tracts. Elife 6.

Wen Z, et al. (2014) Synaptic dysregulation in a human iPS cell model of mental disorders. Nature 515:414-418. CrossRef Medline

Williams PR, Marincu BN, Sorbara CD, Mahler CF, Schumacher AM, Griesbeck O, Kerschensteiner M, Misgeld T (2014) A recoverable state of axon injury persists for hours after spinal cord contusion in vivo. Nat Commun 5:5683. CrossRef Medline

Ylera B, Ertürk A, Hellal F, Nadrigny F, Hurtado A, Tahirovic S, Oudega M, Kirchhoff F, Bradke F (2009) Chronically CNS-injured adult sensory neurons gain regenerative competence upon a lesion of their peripheral axon. Curr Biol 19:930-936. CrossRef Medline 